\title{
Contamination of Water Boreholes in Ogbaru Communities, Anambra State, Nigeria by Fungi
}

\author{
Onuorah Samuel", Igwemadu Nkiruka, Odibo Frederick
}

Department of Applied Microbiology and Brewing, Nnamdi Azikiwe University, Nigeria

Copyright $\mathrm{C} 2019$ by authors, all rights reserved. Authors agree that this article remains permanently open access under the terms of the Creative Commons Attribution License 4.0 International License

\begin{abstract}
Ogbaru communities in Anambra State, Nigeria experience heavy flooding during the wet season thereby exposing the boreholes sited there to the risk of contamination by microorganisms. Water samples from fifteen drinking water boreholes in the area were analysed for the presence of fungi during the dry and wet seasons using standard analytical methods. The fungal counts were $3-25 / \mathrm{cfu} / \mathrm{ml}$ and $4-30 \mathrm{cfu} / \mathrm{ml}$ during the dry and wet seasons respectively. The fungi isolated during both seasons were Penicillium chrysogenum, Aspergillus versicolor, Cladophialophora carrioni, Aspergillus terreus, Candida albicans and Rhodotorula glutinis. C. albicans and A. terreus, each were isolated from $20.0 \%$, R. glutinis and C. carrioni each in $13.3 \%$, P. chrysogenum in $33.3 \%$ and $\mathrm{A}$. versicolor in $26.7 \%$ of the boreholes studied during the dry season while C. albicans, R. glutinis and A. terreus each were detected in $26.7 \%$, P. chrysogenum in $40.0 \%$, A. versicolor in $33.3 \%$ and $\mathrm{C}$. carrioni in $20.0 \%$ of the boreholes investigated during the wet season. Aspergillus terreus occurred most frequently $(31.4 \%)$ in the borehole water samples during the dry season while Penicillium chrysogenum had the highest frequency of occurrence of $28.3 \%$ during the wet season. All the borehole water samples analysed were contaminated by fungi and must undergo adequate treatment such as sand filtration chlorination, aeration and boiling before use.
\end{abstract}

Keywords Contamination, Boreholes, Water, Ogbaru Communities, Nigeria, Fungi

\section{Introduction}

Ground water can be contaminated by naturally occurring sources. Soil and geological formation containing high levels of heavy metals can leach them into ground water. Pollution caused by fertilizers and pesticides used in agriculture is a great threat to fresh ground water ecosystems. The quality of ground water is a function of natural processes as well as anthropogenic activities [1].

Unsafe water is a global health threat, placing humans at risk to a host of diseases such as diarrhea as well as chemical intoxication [2]. It has devastating effect on young children in developing world. Each year, more than two million persons, mostly children under five years of age, die of diarrhea [3]. Groundwater pollution not only affects water quality but also threatens human health, economic development and social prosperity [4]. Ground water is generally less susceptible to contamination and pollution when compared to surface water bodies [5]. The natural impurities in rainwater which replenishes groundwater systems are removed during infiltration through the soil strata. Man's activities such as food production and nutrition are dependent on water availability in adequate quantities and good quality.

Many developing countries suffer from either chronic shortages of fresh water or the readily accessible water resources are heavily polluted [6]. The evaluation of potable water supplies for coliform bacteria is important in determining the sanitary quality of drinking water. High levels of coliform counts indicate a contaminated source, inadequate treatment or post treatment deficiencies. Faecal coliforms differ from the other members of the group on the grounds that they tolerate and grow at higher temperature of $45^{\circ} \mathrm{C}$ [7].

Total coliforms, faecal coliforms, Enterobacter faecalis and Clostridium perfringens are used to assess the biological quality of water, with little or no attention paid to the fungi. Fungi are a significant cause of water pollution and many of them are human pathogens that have been reported to grow on land and in water [8].

Borehole water is the major source of drinking water for the inhabitants of the communities. It is estimated that about two hundred individuals, which is a significant part of the entire population obtain their drinking water from each of the boreholes on daily basis, therefore in this work, the fungal contamination of the water boreholes in Ogbaru communities which are located on the shores of River Niger, in Anambra State of Nigeria was studied. 


\section{Materials and Methods}

\subsection{Samples Collection and Processing}

Water samples were collected from fifteen drinking water boreholes in Ogbaru communities during the dry (Jan-March) and wet (April-June) seasons in 2018. The boreholes were cited in the following locations.

1. Odunze Street Atani

2. Abiribose Atani

3. Ujadimegwu Atani

4. Ochuche

5. Akili-Ozizor

6. Cathedral Road Atani

7. Umundu Ohita

8. Odekpe

9. Iyiowa Odekpe

10. Okoti Odekpe

11. Okpotuno Odekpe

12. Atani Road Okoti

13. Okpoko

14. Imeogbe

15. Anibueze Odekpe

The samples were collected in triplicates in sterile one litre plastic containers with screw caps and transported in an ice pack to the microbiology laboratory of Nnamdi Azikiwe University, Awka, Nigeria within one hour of collection. The samples were thoroughly mixed by inverting the containers for twenty five times and were analysed with twenty four hours of collection.

\subsection{Fungal Counts}

The method described by Onuorah et al.[9] was used. Sabouraud Dextrose Agar (SDA) was prepared based on the manufacturer's instruction and sterilized in the autoclave at $121^{\circ} \mathrm{C}$ for fifteen minutes. Upon cooling to $45^{\circ} \mathrm{C}$, it was dispensed into culture plates. Chloramphenicol $(0.05 \mathrm{mg} / \mathrm{ml})$ was added to the plates to inhibit bacterial growth. One milliliter of the water sample was dispensed into the centre of the SDA and spread evenly over the agar surface. Incubation was carried out in an inverted position at $28^{\circ} \mathrm{C}$ for five days after which the colonies were counted and the result recorded. Each colony was subcultured and stored on sterile SDA slant for characterization and identification.

\subsection{Characterization and Identification of the Fungal Isolates}

The fungi were characterized as described by Onuorah et al. [9]. Colony morphology, cellular morphology, germ tube test, slide culture, gram staining, sugar fermentation test, motility test, urease test and lactophenol cotton blue staining were carried out. Molecular characterization was also carried out using $17 \mathrm{~S}$ rRNA. They were identified as described by David et al. [10].

\subsection{Statistical Analysis}

Pearson correlation coefficient was used to test for the linear relationship between the data obtained for both seasons. The critical value was determined using the t-distribution table.

\section{Results}

The fungal counts of the water boreholes investigated in Ogbaru communities during the dry and wet seasons are presented in Table 1. The counts during the dry season ranged from 3 to $25 \mathrm{cfu} / \mathrm{ml}$ and $4-30 \mathrm{cfu} / \mathrm{ml}$ during the wet season.

Table 1. Fungal counts of the water boreholes investigated in Ogbaru communities during the dry and wet seasons

\begin{tabular}{|l|l|l|}
\hline Borehole location & $\begin{array}{l}\text { Dry season } \\
\text { (cfu/ml) }\end{array}$ & $\begin{array}{l}\text { Wet } \\
\text { (cfu/ml) }\end{array}$ \\
\hline Odunze Street Atani & 8 & 9 \\
\hline Abiribose Atani & 6 & 7 \\
\hline Ujadimegwu Atani & 6 & 8 \\
\hline Ochuche & 3 & 4 \\
\hline Akili-Ozizor & 19 & 20 \\
\hline Cathedral Road Atani & 5 & 6 \\
\hline Umundu Ohita & 11 & 13 \\
\hline Odekpe & 7 & 8 \\
\hline Iyiowa Odekpe & 9 & 11 \\
\hline Okoti Odekpe & 8 & 19 \\
\hline Okpotuno Odekpe & 10 & 14 \\
\hline Atani Road Okoti & 13 & 14 \\
\hline Okpoko & 25 & 30 \\
\hline Imeogbe & 12 & 16 \\
\hline Anibueze Odekpe & 11 & 12 \\
\hline & & \\
\hline
\end{tabular}

The colonial and microscopic characteristics of the moulds isolated from the water boreholes investigated in Ogbaru communities during the dry and wet seasons are shown in Table 2. They were identified as Penicillium chrysogenum, Aspergillus versicolor, Cladophialophora carrioni and Aspergillus terreus. 
Table 2. Colonial and microscopic characteristics of the moulds isolated from the water boreholes investigated in Ogbaru communities during the dry and wet season

\begin{tabular}{|c|c|c|c|}
\hline Isolates & Colonial Characteristics & Microscopic Characteristics & Identity \\
\hline 1. & $\begin{array}{l}\text { Colonies were rapidly growing, velvety to powdery in } \\
\text { texture and greenish on the surface. }\end{array}$ & $\begin{array}{l}\text { Hyphae were septate, hyaline with simple conidiophores. Conidia were } \\
\text { unicellular, round and pigmented. }\end{array}$ & Penicillium chrysogenum \\
\hline 2. & $\begin{array}{l}\text { Colonies were greenish in colour and slow growing with } \\
\text { musty odour. }\end{array}$ & $\begin{array}{l}\text { Hyphae were long and septate and appeared transparent. Conidia were spherical } \\
\text { and had smooth surfaces. }\end{array}$ & Aspergillus versicolor \\
\hline 3. & $\begin{array}{l}\text { Colonies were black in colour and were slow growing with } \\
\text { compact downy surface. }\end{array}$ & $\begin{array}{l}\text { Conidiophores produced chains of conidia. Conidia were small and had heavily } \\
\text { branched systems. }\end{array}$ & $\begin{array}{l}\text { Cladophialophora } \\
\text { carrioni }\end{array}$ \\
\hline 4. & Colonies were fast growing and brown in colour. & $\begin{array}{l}\text { Conidiophores were smooth and hyaline. Conidia heads were compact, biseriate } \\
\text { and densely columnar. }\end{array}$ & Aspergillus terreus \\
\hline
\end{tabular}

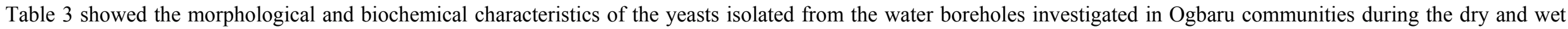
seasons. The yeasts were identified as Candida albicans and Rhodotorula glutinis.

Table 3. Morphological and biochemical characteristics of the Yeasts isolated from the water boreholes investigated in Ogbaru communities during the dry and wet seasons.

\begin{tabular}{|c|c|c|c|c|c|c|c|c|c|c|}
\hline Isolate & Colour & Shape & Urease test & $\begin{array}{l}\text { Germ tube } \\
\text { test }\end{array}$ & $\begin{array}{c}\text { Motility } \\
\text { test }\end{array}$ & $\begin{array}{c}\text { Gram } \\
\text { Staining }\end{array}$ & $\begin{array}{c}\text { Glucose } \\
\text { Fermentation test }\end{array}$ & $\begin{array}{c}\text { Lactose } \\
\text { Fermentation test }\end{array}$ & $\begin{array}{c}\text { Sucrose } \\
\text { Fermentation test }\end{array}$ & Identity \\
\hline 1. & Cream & Round & - & + & - & + & + & - & - & Candida albicans \\
\hline 2. & Cream & Round & + & - & - & + & + & - & - & Rhodotorula glutinis \\
\hline
\end{tabular}

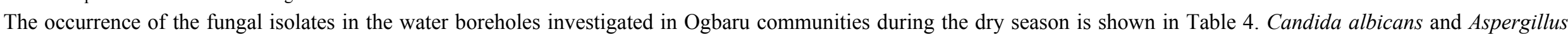

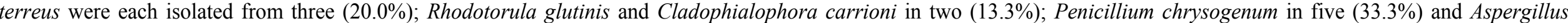
versicolor in four $(26.7 \%)$ of the boreholes investigated.

Table 4. Occurrence of the fungal isolates in the water boreholes investigated in Ogbaru communities during the dry season

\begin{tabular}{|c|c|c|c|c|c|c|}
\hline Borehole location & Candida albicans & Rhodotorula glutinis & Penicillium chrysogenum & Aspergillus versicolor & Cladophialophora carrioni & Aspergillus terreus \\
\hline Odunze Street Atani & - & - & + & - & - & - \\
\hline Abiribose Atani & - & - & - & + & - & - \\
\hline Ujadimegwu Atani & + & - & - & + & - & - \\
\hline Ochuche & - & - & - & - & + & - \\
\hline Akili-Ozizor & - & - & - & + & - & - \\
\hline Cathedral Road Atani & + & + & - & - & - & - \\
\hline Umundu Ohita & - & - & + & - & - & - \\
\hline Odekpe & - & - & - & - & + & - \\
\hline Iyiowa Odekpe & - & - & + & - & - & - \\
\hline Okoti Odekpe & + & + & + & - & - & - \\
\hline Okpotuno Odekpe & - & - & - & + & - & - \\
\hline Atani Road Okoti & - & - & + & - & - & - \\
\hline Okpoko & - & - & - & - & - & + \\
\hline Imeogbe & - & - & - & - & - & + \\
\hline Anibueze Odekpe & - & - & - & - & - & + \\
\hline
\end{tabular}

$+=$ detected $\quad-=$ not detected 
Table 5 showed the occurrence of the fungal isolates in the water boreholes investigated in Ogbaru communities during the wet season. Candida albicans, Rhodotorula glutinis and Aspergillus terreus were each detected in four (26.7\%); Penicillium chrysogenum in six (40.0\%); Aspergillus versicolor in five (33.3\%) and Cladophialopora carrioni in three $(20.0 \%)$ of the boreholes water analysed.

Table 5. Occurrence of the fungal isolates in the water boreholes investigated in Ogbaru communities during the wet season

\begin{tabular}{|c|c|c|c|c|c|c|}
\hline Borehole location & $\begin{array}{l}\text { Candida } \\
\text { albicans }\end{array}$ & $\begin{array}{c}\text { Rhodotorula } \\
\text { glutinis }\end{array}$ & $\begin{array}{c}\text { Penicillium } \\
\text { chrysogenum }\end{array}$ & $\begin{array}{l}\text { Aspergillus } \\
\text { versicolor }\end{array}$ & $\begin{array}{c}\text { Cladophialophora } \\
\text { carrioni }\end{array}$ & $\begin{array}{c}\text { Aspergillus } \\
\text { terreus }\end{array}$ \\
\hline Odunze Street Atani & - & - & + & - & - & - \\
\hline Abiribose Atani & - & - & - & + & - & - \\
\hline Ujadimegwu Atani & + & - & - & + & - & - \\
\hline Ochuche & - & - & - & + & + & - \\
\hline Akili-Ozizor & - & + & - & + & - & - \\
\hline Cathedral Road Atani & + & + & - & - & - & - \\
\hline Umundu Ohita & - & - & + & - & - & - \\
\hline Odekpe & - & - & - & - & + & - \\
\hline Iyiowa Odekpe & - & - & + & - & - & + \\
\hline Okoti Odekpe & + & + & + & - & - & - \\
\hline Okpotuno Odekpe & - & - & - & + & - & - \\
\hline Atani Road Okoti & - & - & + & - & - & - \\
\hline Okpoko & - & + & - & - & + & + \\
\hline Imeogbe & - & - & + & - & - & + \\
\hline Anibueze Odekpe & + & - & - & - & - & + \\
\hline
\end{tabular}

The frequency of occurrence of the fungal isolates in the water boreholes investigated in Ogbaru communities during the dry season is presented in Table 6. Aspergillus terreus had the highest frequency of occurrence of $31.4 \%$ while Rhodotorula glutinis had the lowest frequency of occurrence of $3.3 \%$ in the water boreholes studied.

Table 6. Frequency of occurrence of the fungal isolates in the water boreholes investigated in Ogbaru communities during the dry season.

\begin{tabular}{|l|l|l|}
\hline Fungal Isolates & $\begin{array}{l}\text { Number of } \\
\text { colonies isolated }\end{array}$ & $\begin{array}{l}\text { Frequency occurrence (\%) } \\
\text { of }\end{array}$ \\
\hline $\begin{array}{l}\text { Candida } \\
\text { albicans }\end{array}$ & 9 & 5.9 \\
\hline $\begin{array}{l}\text { Rhodotorula } \\
\text { glutinis }\end{array}$ & 5 & 3.3 \\
\hline $\begin{array}{l}\text { Penicillium } \\
\text { chrysogenum }\end{array}$ & 43 & 28.1 \\
\hline $\begin{array}{l}\text { Aspergillus } \\
\text { versicolor }\end{array}$ & 38 & 24.8 \\
\hline $\begin{array}{l}\text { Cladophialophora } \\
\text { carrioni }\end{array}$ & 10 & 6.5 \\
\hline $\begin{array}{l}\text { Aspergillus } \\
\text { terreus }\end{array}$ & 48 & 31.4 \\
\hline Total & 153 & 100.0 \\
\hline
\end{tabular}

The frequency of the fungal isolates in the water boreholes investigated in Ogbaru communities during the wet season is shown in Table 7. Penicillium chrysogenum occurred most frequently (28.3\%) while Cladophialophora carrioni had the least frequency of occurrence of $9.4 \%$ in the water boreholes investigated.

Table 7. Frequency of occurrence of the fungal isolates in the water boreholes investigated in Ogbaru communities during the wet season.

\begin{tabular}{|l|l|l|}
\hline Fungal Isolates & $\begin{array}{l}\text { Number of } \\
\text { colonies isolated }\end{array}$ & $\begin{array}{l}\text { Frequency oc } \\
\text { occurrence (\%) }\end{array}$ \\
\hline $\begin{array}{l}\text { Candida } \\
\text { albicans }\end{array}$ & 31 & 16.2 \\
\hline $\begin{array}{l}\text { Rhodotorula } \\
\text { glutinis }\end{array}$ & 28 & 14.7 \\
\hline $\begin{array}{l}\text { Penicillium } \\
\text { chrysogenum }\end{array}$ & 54 & 28.3 \\
\hline $\begin{array}{l}\text { Aspergillus } \\
\text { versicolor }\end{array}$ & 35 & 18.3 \\
\hline $\begin{array}{l}\text { Cladophialophora } \\
\text { carrioni }\end{array}$ & 18 & 9.4 \\
\hline $\begin{array}{l}\text { Aspergillus } \\
\text { terreus }\end{array}$ & 25 & 13.1 \\
\hline Total & 191 & 100.0 \\
\hline
\end{tabular}

\section{Discussion}

The fungal counts of the water boreholes investigated in Ogbaru communities were $3-25 \mathrm{cfu} / \mathrm{ml}$ and $4-30 \mathrm{cfu} / \mathrm{ml}$ during the dry and wet seasons respectively (Table 1). More fungi were isolated from the samples during the wet than the dry season, indicating that the wet season favoured the growth of the fungi more than the dry season. Onuorah et al. [9] studied the mycology of hand-dug shallow water 
wells in Awka metropolis, Anambra State and isolated more fungi during the wet than the dry season. The preponderance of fungi during the wet season may be attributed to the deposition of nutrients and microorganisms including fungi by flood in the soil around the boreholes and their infiltration into the ground water.

The moulds isolated from the water samples during both seasons were identified as Penicillium chrysogenum, Aspergillus versicolor, Cladophialophora carrioni and Aspergillus terreus (Table 2) while the yeasts isolated during both seasons were Candida albicans and Rhodotorula glutinis (Table 3) .Onuorah et al. [9] reported the presence of Candida albicans in the shallow water wells in Awka metropolis, Nigeria while Warris et al. [11], Hayette et al. [12] and Anaissie et al. [13] isolated Aspergillus species from the drinking water samples they assessed. More of the boreholes were contaminated with the fungal isolates during the wet than the dry season (Tables 4 and 5). This result also agreed with the report of Onuorah et al. [9] on the mycology of hand-pump shallow water wells in Awka metropolis, Nigeria.

Aspegillus terreus occurred most frequently (31.4\%) in the water samples studied during the dry season while the yeast Rhodotorula glutinis had the lowest frequency of occurrence of $3.3 \%$ in the water samples analysed during the dry season. However, Penicillium chrysogenum had the highest frequency of occurrence of $28.3 \%$ in the water samples examined during the wet season while Cladophialophora carrioni had the least frequency of occurrence of $9.4 \%$ in the water samples studied during the wet season. Warris et al. [11] however reported that $21 \%$ of the drinking samples they examined were contaminated with Aspergillus species while Anaissie et al. [13] isolated Aspegillus species from more than $70 \%$ of all the drinking water samples they examined. The variation in the values may be attributed to the method of analysis, the time between sample collection and analysis, the sanitary condition of the boreholes sites and prevailing environmental conditions.

Penicillium chrysogenum inhabits a wide range of habitats including moist soils with plentiful quantities of carbon and nitrogen for mycorrhizal growth and is also one of the most frequent organisms found in water. It plays a role in the medical community as either a pathogen [14] or allergen [15] and is a cause of infection in people with severely suppressed immune systems. It's implication in allergy, asthma as well as other respiratory problems have been reported [16]. Aspergillus versicolor is a slow-growing filamentous fungus that is highly ubiquitous and commonly isolated from the soil, plant debris, marine environments and indoor air environments. It is an opportunistic pathogen and an important causative agent of Aspergillosis. There have been reported cases of the fungus causing onchomycosis [17].

Cladophialophora carrioni is a saprophytic fungus occurring mainly on decaying plant materials such as wood and the soil and is one of the most common agents of Chromoblastomycosis. Infection by this fungus causes inflammation of the leg or foot tissue resulting in granulomas [18]. Aspergillus terreus is a mold found worldwide in warm, arable soil, decomposing vegetation and dust and is considered as an emerging agent of infection. It is an opportunistic pathogen and is able to cause systemic and superficial infections [19], respiratory infections, onchomycosis and otomycosis [20].Candida albicans is a flora of the gastrointestinal tract in $40 \%$ of healthy adults [21] and one of the genera that causes candidiasis in humans [22]. It is also a dimorphic fungus that is responsible for $50-90 \%$ of all cases of candidiasis of humans.

Rhodotorula glutinis is distributed widely and is most often found in the soil, air, phyllosphere, agricultural products and is a commensal of mammals including humans, occurring commonly on the skin and in the stool [23]. The fungus causes localized infections such as meningitis and peritonitis as well as fungemia in patients with underlying diseases or immunosupression such as cancer or leukemia and AIDS patients [24].The fungal counts were significant at $5 \%$ significance level using t-distribution indicating that the season had pronounced effects on their growth and proliferation. The water boreholes assessed were contaminated with pathogenic fungi and need adequate treatment before drinking by humans to avert a public health hazard.

\section{Conclusions}

The water boreholes analysed during both seasons were contaminated by fungi which have been reported to cause various diseases. Adequate treatment of the boreholes water such as chlorination, boiling, sand filtration and aeration should be undertaken to prevent the occurrence of fungal water-borne diseases. The boreholes in the area should be sited at a safe distance from refuse dumps, pit latrines and septic tanks. The users of such water should be educated on the need for the maintenance of adequate hygiene and sanitation. In addition, regular monitoring and periodic analysis of the water from the boreholes for the presence of fungi must be carried out. Regular fumigation of the soil in the communities is also recommended.

\section{REFERENCES}

[1] Badmus, B. S., Odewande, A. A., Ayolabi, E. A. and Ayodele, T. (2009). Experimental investigation of leachate contamination of ground water exploration in basement complex area. Journal of Natural Sciences, Engineering and Technology. 8(1):11-15.

[2] Hughes, J. M. and Koplan, J. P. (2005). Saving lives through global safe water. Journal of Emerging Infectious 
Diseases. 11(10):1636-1637.

[3] Kosek, M; Bern, C. and Guerrant, R. L. (2003). The global burden of diarrheal disease as estimated from studies published between 1992 and 2000. Bulletin of World Health Organization. 81:197-204.

[4] Milovanovic, M. (2007). Water quality assessment and determination of pollution sources along the Axios/Vadar River, Southeastern Europe. Desalination. 213(1-3): 159-173.

[5] Zeman, C. L, Kross, B. and Vlad, M. (2002). A nested case control study of methanoglobinaemia, risk factor in children of Transylvania, Romania. Environmental Health Prospectives. 110(8):817-822.

[6] Lehloesa, L. J. and Muyima, N. Y. O. (2000). Evaluation of the impact of household treatment procedures on the quality of ground water supplies in the rural community of the Victoria District, Eastern Cape. Water SA. 26(2):285-290.

[7] Szewzyk, V; Szewzyk, R; Manz, W. and Scheleifer, K.H. (2002). Microbiological safety of drining water. Annual Review of microbiology. 54:81-127.

[8] Cabral, D; Virginia, E. and Fernandez, P. (2002). Fungal spoilage of bottled mineral water. International Journal of Food Microbiology. 72(1-2):73-76.

[9] Onuorah Samuel, Elesia Rosemary and Odibo Frederick (2016). Mycology of hand-dug shallow water wells in Awka Metropolis, Anambra State, Nigeria, Advances in Zoology and Botany. 4(2):17-22.

[10] David, E; Stephen, D; Helen, A; Rosemary, H. and Robyn, B. (2007). Descriptions of medical fungi. Mycology Unit Women's and Children Hospital, School of molecular and biomedical science, University of Adelaide, $2^{\text {nd }}$ edition. Pp 58.

[11] Warris, A; Gaustad, P; Meis, J. F; Voss, A; Verweij, P. E. and Brahamsen, T.G. (2001), Recovery of filamentous fungi from water in a paediatric bone marrow transplantation unit. Journal of Hospital Infection. 47:143-148

[12] Hayette, M. P., Christiaens, G; Mutsers, J., Barbier, C; Huynen, P; Melin, P. and De Mol, P. (2010). Filamentous fungi recovered from the water distribution system of a Belgian University Hospital. Medical Mycology official publication of the International Society for Human and Animal Mycology. 48(7):969-974.

[13] Anaissie, E. J., Stratton, S. L; Dignani, M. C; Lee, C. K; Summerbell, R. C. and Rex, J. H. (2002). Pathogenic Aspergillus species recovered from a hospital water system: a 3-year prospective study. Clinical Infectious Diseases. 34: 780-789.

[14] Barchus, A. L; Burdette, S. D and Herchline, T. E. (2005). Intestinal invasion and disseminated disease associated with Penicillium chrysogenum. Annals of Clinical Microbiology and Antimicrobials. 4:21.

[15] Shen, H. D., Chou, H; Tam, M. F., Chang, C. Y., Lai, H.Y. and Wang, S. R. (2003). Molecular and immunological characterization of Pench 18, the vacuolar serine protease major allergen of Penicillium chrysogenum. European Journal of Allergy and Clinical Immunology. 58(10):
993-1002.

[16] Denning, D. W; O'Driscoll, B. R; Hogaboam, C. M; Bowyer, P. and Niven, R. N. (2006). The link between fungi and severe asthma: a summary of the evidence. The European Respiratory Journal. 27(3): 615-626.

[17] Fomicheva, F. M; Vasilenko, O. V. and Marfenina, O. E. (2006). Comparative morphological, ecological and molecular studies of Aspergillus versicolor (vuill.) Tiraboschi strains isolated from different ecotypes. Microbiology. 75(2): 186-191.

[18] de Hoog, G. S; Nishikaku, A. S; Fernandez-Zeppenfeldt, G; Padin-Gonzalez, C; Burga, E. A; Badali, H; Richard-Yegres, N. and Gerrits, A. G. H. (2007). Molecular analysis and pathogenicity of the C. carrioni complex with the description of novel species. Studies in Mycology. 58: 219-234.

[19] Lass-Florl, C; Griff, K; Mayr, A; Petzer, A; Gastl, G; Bonatti, H; Freund, M; Kropshofer, G; Dierich, M. and Nachbaur, D. (2005). Epidemiology and outcome of infections due to Aspergillus terreus: 10-year single centre experience. British Journal of Haematology. 131(2): 200-207.

[20] Fernandez, M; Rojas, F; Cattana, M; Sosa, M; Mangiaterra, M. and Giusiano, G. (2013). Aspergillus terreus complex. an emergent opportunistic agent of Onchomycosis. Mycoses. 56(4): 477-481.

[21] Mukherjee, P. K; Sendid, B; Hoarau, G; Colombel, J. F; Poulain, D. and Ghannoum, M.A. (2015). Mycobiota in gastrointestinal diseases. Nature Reviews. Gastroenterology and Hepatology 12(2): 77-87.

[22] Martins, N; Ferreira, I. C; Barros, L; Silva, S. and Henriques, M. (2014). Candidiasis: Predisposing factors, prevention, diagnosis and alternative treatment. Mycopathologia 177(5-6): 223-240.

[23] Erdogan, A. and Rao, S. S. (2015). Small intestinal fungal overgrowth, Current Gastroenterology Reports. 17(4):16.

[24] Miceli, M. A; Diaz, J. A. and Lee, S. A. (2011). Emerging opportunistic yeast infections. The Lancet. Infectious Diseases. 11(2): 142-151. 